\title{
PENGARUH MUKA AIR TANAH TERHADAP TEGANGAN EFEKTIF TANAH DASAR CANDI PRAMBANAN BERDASAR METODE ELEMEN HINGGA
}

\author{
Tri Wahyu Kuningsih ${ }^{1}$ dan Dwi Novi Wulansari ${ }^{2}$ \\ ${ }_{1,2}^{1,2}$ iviversitas 17 Agustus 1945 Jakarta, Jalan Sunter Permai Raya \\ Email: 1triwahyukuningsih@yahoo.co.id, 르op_phi13@yahoo.com
}

\begin{abstract}
Indonesia which geographically has an area located at $6^{\circ} \mathrm{LU}$ up to $11^{\circ} \mathrm{LS}$ and $97^{\circ} \mathrm{BT}$ up to $141^{\circ} \mathrm{BT}$ is an area prone to earthquakes. Determination of the temple as a world cultural heritage has implications for the responsibilities and obligations of the Indonesian people in an effort to protect and maintain the building in accordance with the conventions set by UNESCO. The convention, among others, is maintaining the preservation of buildings from the dangers of war, physical damage due to age, and natural disasters. This research was conducted with the aim to determine the effect of groundwater depth and earthquake acceleration on the strength of Prambanan Temple subgrade based on finite element method. Simplification of Siwa Temple as a modeling in software input. The results of the study are the shallower depth of the ground water level, the effective stress of the soil will also be reduced. When effective stress decreases, the strength of the soil will also decrease. The deeper the depth of the water table, the effective stress of the soil increases. The depth of the ground water level affects the amount of excess pore pressure. The more shallow the depth of the ground water level, the amount of excess pore pressure will also increase even the value is positive. The deeper the depth of the ground water level, the greater the amount of excess pore pressure decreases even the value is negative.
\end{abstract}

Key words : Prambanan Temple, effective stresses, excess pore pressure

\begin{abstract}
ABSTRAK
Indonesia yang secara geografis mempunyai wilayah yang terletak pada $6^{\circ} \mathrm{LU}$ sampai dengan $11^{\circ} \mathrm{LS}$ serta $97^{\circ} \mathrm{BT}$ sampai dengan $141^{\circ}$ BT merupakan daerah yang rawan terhadap gempa bumi. Penetapan candi sebagai warisan budaya dunia berimplikasi pada tanggung jawab dan kewajiban bangsa Indonesia dalam upaya melakukan pelindungan dan pemeliharaan bangunan tersebut sesuai dengan konvensi yang telah ditetapkan oleh UNESCO. Konvensi tersebut antara lain menjaga pelestarian bangunan dari bahaya perang, kerusakan fisik karena termakan usia, dan bencana alam. Penelitian ini dilakukan dengan tujuan untuk mengetahui pengaruh kedalaman muka air tanah dan percepatan gempa terhadap kekuatan tanah dasar Candi Prambanan berdasar metode elemen hingga. Ilustrasi penyederhanaan Candi Siwa sebagai pemodelan dalam input perangkat lunak. Hasil penelitian adalah semakin dangkal kedalaman muka air tanah, maka tegangan efektif tanah juga akan berkurang. Pada saat tegangan efektif berkurang maka kekuatan tanah juga akan berkurang. Semakin dalam kedalaman muka air tanah, tegangan efektif tanah semakin meningkat. Kedalaman muka air tanah mempengaruhi besarnya excess pore pressure. Semakin dangkal kedalaman muka air tanah, besarnya excess pore pressure juga akan meningkat bahkan nilainya positif. Semakin dalam kedalaman muka air tanah, besarnya excess pore pressure semakin menurun bahkan nilainya negatif.
\end{abstract}

Kata kunci : candi prambanan, tegangan efektif, excess pore pressure.

\section{PENDAHULUAN}

\section{Latar Belakang}

Indonesia yang secara geografis mempunyai wilayah yang terletak pada $6^{\circ} \mathrm{LU}$ sampai dengan $11^{\circ} \mathrm{LS}$ serta $97^{\circ}$ BT sampai dengan $141^{\circ}$ BT merupakan daerah yang rawan terhadap gempa bumi. Hal tersebut disebabkan karena wilayah Indonesia terletak pada pertemuan tiga lempeng tektonik, yaitu lempeng pasifik, lempeng indo-australia dan lempeng eurasia. Keberadaan Indonesia pada pertemuan tiga lempeng tektonik tersebut, memicu sering terjadinya peristiwa gempa bumi tektonik. Selain kondisi seismotektonik 
tersebut, wilayah Indonesia secara seismovulkanik juga merupakan pertemuan dari dua lingkaran barisan gunung api, yaitu: sirkum pasifik dan sirkum mediterania. Bilamana salah satu gunung api yang ada di wilayah Indonesia tersebut mengalami aktifitas vulkanik maka akan memicu terjadinya gempa bumi vulkanik [1].

Kompleks Candi Prambanan telah ditetapkan sebagai salah satu warisan budaya dunia (World Heritage) oleh UNESCO pada tahun 1991, bernama Prambanan Temple Compound. Selain Candi Prambanan, Prambanan Temple Compound di dalamnya terdapat beberapa candi berlatar belakang agama Budha, yaitu : Kompleks Candi Sewu, Candi Lumbung, Candi Bubrah, dan Candi Asu (Gana). Penetapan candi sebagai warisan budaya dunia berimplikasi pada tanggung jawab dan kewajiban bangsa Indonesia dalam upaya melakukan pelindungan dan pemeliharaan bangunan tersebut sesuai dengan konvensi yang telah ditetapkan oleh UNESCO. Konvensi tersebut antara lain menjaga pelestarian bangunan dari bahaya perang, kerusakan fisik karena termakan usia, dan bencana alam [2].

\section{Tujuan}

Penelitian ini dilakukan dengan tujuan untuk mengetahui pengaruh kedalaman muka air tanah dan percepatan gempa terhadap kekuatan tanah dasar Candi Prambanan berdasar metode elemen hingga.

\section{Tinjauan Pustaka}

\section{Perilaku Tegangan - Regangan Pasir}

Tanah pasir longgar memiliki perilaku daktail, dan tegangan geser naik secara perlahan-lahan seiring pertambahan regangan dan pasir padat akan berperilaku lebih kaku. Tegangan geser akan meningkat seiring pertambahan regangan sampai mencapai suatu nilai tegangan geser maksimum, kemudian nilainya akan turun. Untuk tanah pasir dengan kepadatan sedang akan memiliki perilaku diantara perilaku pasir dengan kepadatan tinggi dan rendah. Semakin Perilaku tegangan - regangan pasir sangat tergantung pada padat suatu tanah pasir, semakin besar kekuatan yang dimiliki oleh tanah tersebut. Pada Gambar 1, bagian yang diarsir mewakili tambahan kekuatan pasir akibat fenomena interlocking yang terjadi pada pasir dengan kepadatan tinggi [3].

Pada pasir longgar yang dibebani tegangan geser akan memiliki kecendrungan untuk memadat / mengkerut (contractancy). Pengurangan volume berarti ruangan yang lebih sedikit tersedia untuk air pori. Air pori harus mengalir keluar dari tanah, tapi hal ini memerlukan beberapa waktu, pada kasus pembebanan dengan kecepatan tinggi kecendrungan pengurangan volume akan mengakibatkan peningkatan tekanan pori dalam air. Tekanan efektif akan berkurang dan tanah akan menjadi lebih lemah. Ketika tekanan efektif berkurang sampai nol, tanah akan kehilangan kekuatannnya, peristiwa ini disebut likuifaksi [5].

\section{Stress Path}

Saat pembebanan diberikan pada sampel tanah, kombinasi perubahan dalam tegangan geser dan tegangan efektif menyebabkan keruntuhan tanah. Perubahan dalam tegangan efektif disebabkan oleh perubahan dalam tegangan normal total, tekanan air pori, atau keduanya. Di bawah kondisi geser tak terdrainasi di lapangan dan laboratorium, tekanan pori yang disebabkan oleh geser dapat menaikan atau menurunkan tegangan efektif pada permukaan geser. Salah satu cara untuk memonitor perubahan tegangantegangan ini dengan memunculkan lingkaran tegangan Mohr pada setiap tahapan loading/unloading [5]. 
Stress path adalah kurva atau garis lurus yang merupakan tempat titik-titik tegangan yang menggambarkan perubahan tegangan dalam sampel uji (beban yang diatur dalam uji triaksial) atau tanah in-situ (pembebanan yang disebabkan alam), selama loading atau unloading [4]. Ilustrasi stress path untuk kasus $\sigma \_1$ meningkat dan $\sigma \_3$ konstan dapat dilihat pada Gambar $\overline{2}$ di bawah ini.

\section{Gempa di Indonesia}

Beberapa gempa-gempa besar signifikan yang pernah terjadi di Indonesia disajikan pada Gambar 3 di bawah ini. Nilai Peak Ground Accelaration (PGA) yang dicantumkan pada tabel merupakan PGA yang berada di kota-kota besar di Indonesia dengan asumsi padatnya penduduk dan struktur penting yang berarti kerusakan terjadi menyebabkan kerugian yang lebih besar.

\section{Cyclic Shear Strain Threshold}

Penelitian yang dilakukan

Kusumawardhani [8], pada Gambar 4 menunjukan perilaku kenaikan tekanan air pori pada benda uji yang berupa clean sand ketika diterapkan frekuensi beban (f) sebesar 0,1 Hz. Selama uji dilakukan, nilai rasio tekanan air pori dicatat secara detail dari awal hingga akhir uji. Untuk hasil pencatatan digunakan tekanan air pori residual $\left(\Delta \mathrm{u} \_r\right)$. Tekanan air pori residual $\left(\Delta \mathrm{u} \_r\right.$ ) menggambarkan komponen tekanan air pori yang tidak dipengaruhi oleh beban siklis yang diterapkan. Variasi nilai $\gamma_{\_} \varepsilon$ yang diterapkan pada benda uji mulai $2.10-3 \%$ hingga $1.10-1 \%$. Pencatatan nilai untuk setiap amplitudo cyclic shear strain, kemudian dinormalisasi dengan tegangan efektif sel $\left(\sigma^{\wedge \prime} 3\right)$, akan didapatkan rasio tekanan air pori residual $\left(\left(\Delta u_{-} r\right)\left(\sigma^{\wedge \prime}\right.\right.$ $3)$ ). Nilai cyclic threshold shear strain $\left(\gamma_{-} \mathrm{t}\right)$, diperoleh dari grafik hubungan antara amplitudo cyclic shear strain $\left(\gamma \_\varepsilon\right)$ dan rasio tekanan air pori residual $\left(\left(\bar{\Delta} u_{-} \mathrm{r}\right)\left(\sigma^{\wedge \prime} 3\right)\right)$. Titik di mana mulai terjadi kenaikan rasio tekanan air pori residual dinyatakan sebagai cyclic threshold shear strain $\left(\gamma_{-} \mathrm{t}\right)$.

Untuk Gambar 5 diperoleh dengan menerapkan kondisi pembebanan yang sama, perbedaannya hanyalah pada nilai frekuensi (f) beban yaitu sebesar 0,05 Hz. Dari kedua gambar tersebut diperoleh kesimpulan bahwa besarnya amplitudo cyclic threshold shear strain $\left(\gamma_{-} \mathrm{t}\right)$ ketika diterapkan tegangan efektif sel $\left(\sigma^{\wedge \prime} 3\right)$ sebesar $100 \mathrm{kPa}$ pada tiga jenis kondisi kepadatan tanah dengan nilai kepadatan relatif tanah (Dr) yang berbeda yaitu 25\%, 60\% dan 80\% untuk frekuensi pembebanan (f) $=0,05$ maupun $0,1 \mathrm{~Hz}$ mempunyai kisaran nilai yang sama yaitu antara 1.10-2 \% hingga $2.10-2 \%$.

Dari Gambar 4 dan 5 disimpulkan jika diterapkan nilai $\gamma_{-} \varepsilon<\gamma_{-}$t, maka tidak akan ada kenaikan tekanan air pori. Ketika nilai $\gamma_{-} \varepsilon>\gamma_{-}$, maka terlihat adanya pergerakan kenaikan tekanan air pori. Semakin besar nilai amplitudo cyclic shear strain $\left(\gamma_{-} \varepsilon\right)$ yang diterapkan terhadap benda uji, maka akan semakin tinggi tekanan air pori yang terjadi. Parameter kepadatan relatif (Dr) sangat mempengaruhi kenaikan tekanan air pori yang terjadi di dalam benda uji apabila amplitudo cyclic shear strain $\left(\gamma \_\varepsilon\right)$ yang diterapkan selama pengujian lebih besar dari cyclic threshold shear strain $\left(\gamma_{-} \mathrm{t}\right)$. Pernyataan tersebut dibuktikan dengan melihat grafik hubungan antara cyclic shear strain $\left(\gamma_{-} \varepsilon\right)$ dan tekanan air pori residu $\left(\Delta u_{-} r\right.$ ). Dari grafik tersebut tampak bahwa penerapan amplitudo cyclic shear strain $\left(\gamma_{-} \varepsilon\right)$ yang sama pada benda uji kondisi kepadatan benda uji yang berbeda akan menghasilkan pola kenaikan tekanan air pori yang berbeda. Berdasar kedua gambar tersebut menunjukan ketika 
kepadatan relatif (Dr) benda uji sebesar $25 \%$, maka kenaikan tekanan air pori residu $\left(\Delta u \_r\right)$ lebih besar dibandingkan benda uji dengan Dr sebesar 25\%.

\section{METODE PENELITIAN}

\section{Pengumpulan Data}

Untuk melakukan penelitian ini, dibutuhkan data uji lapangan yaitu Standard Penetration Test (SPT) di Pelataran Candi Prambanan Yogyakarta dan data gempa tercatat yang pernah terjadi di Yogyakarta dan sekitarnya berdasarkan Elnashai tahun 1903 2006 [6], Badan Meteorologi Klimatologi dan Geofisika (BMKG) Yogyakarta tahun 2004 - 2015 [9] dan USGS (United State Geology Survey) tahun 1957 - 2015 [10]. Lokasi Candi Prambanan berada di suatu cekungan dan di sebelah timur Candi Siwa dijumpai mata air dan permukaan tanah asli pada kedalaman 14,00 m dari muka tanah di halaman candi [11].

Ilustrasi Penyederhanaan Candi Siwa Bentuk dasar candi Siwa dan perbaikan tanah bawah candi di lapangan berbentuk segi-20. Untuk kemudahan perhitungan, dasar candi pada permukaan tanah dan bagian candi yang berada di bawah permukaan tanah (tanah kapur/limestone) dianggap berbentuk persegi dengan masingmasing $17 \mathrm{~m} \times 17 \mathrm{~m}$ dan $15 \mathrm{~m} \times 15 \mathrm{~m}$ [12].

\section{Pemodelan Elemen Hingga}

Pemodelan elemen hingga dilakukan dengan menggunakan perangkat lunak. Pada Gambar 7 menunjukkan pemodelan tanah dasar Candi Siwa Prambanan dalam perangkat lunak.

\section{HASIL DAN PEMBAHASAN}

Parameter - parameter tanah yang digunakan untuk input program:

Berat Volume Candi $\left(\gamma \_\right.$candi $)$

$$
=1.935 \mathrm{~g} / \mathrm{cm} 3
$$

Luasan Dasar Candi (A_candi )

$$
=2.890 .000 \mathrm{~cm} 2
$$

Berat Volume Batu Kapur ( $\gamma_{-}$(batu

kapur) ) = 2,360 g/cm3

Volume Candi (V_candi )

$$
=4.142 .333 .333 \mathrm{~cm} 3
$$

Berat Batu Candi (W_candi )

$$
=8.015 .415 .000 \mathrm{~g}
$$

\section{Pengaruh Kedalaman Muka Air Tanah Terhadap Tegangan Efektif}

Analisis berdasarkan hasil dari perhitungan dengan metode elemen hingga disajikan pada Gambar 8 di bawah ini. Hasil menunjukkan bahwa kedalaman muka air tanah mempengaruhi tegangan efektif tanah. Semakin dangkal kedalaman muka air tanah, tegangan efektif tanah juga akan menurun. Semakin dalam kedalaman muka air tanah, tegangan efektif tanah semakin meningkat.

Pengaruh Kedalaman Muka Air Tanah Terhadap Excesses Pore Pressure

Analisis berdasarkan hasil dari perhitungan dengan metode elemen hingga disajikan pada Gambar 9 di bawah ini. Hasil menunjukkan bahwa kedalaman muka air tanah mempengaruhi besarnya excess pore pressure. Semakin dangkal kedalaman muka air tanah, besarnya excess pore pressure juga akan meningkat bahkan nilainya positif. Semakin dalam kedalaman muka air tanah, besarnya excess pore pressure semakin menurun bahkan nilainya negatif.

\section{KESIMPULAN}

Dari hasil analisis pemodelan tanah dasar Candi Siwa Prambanan dengan metode elemen hingga di atas dapat disimpulkan bahwa:

a. Semakin dangkal kedalaman muka air tanah, tegangan efektif tanah juga akan berkurang. Pada saat 
tegangan efektif berkurang maka kekuatan tanah juga akan berkurang.

b. Semakin dalam kedalaman muka air tanah, tegangan efektif tanah semakin meningkat.

c. Kedalaman muka air tanah mempengaruhi besarnya excess pore pressure. Semakin dangkal kedalaman muka air tanah, besarnya excess pore pressure juga akan meningkat bahkan nilainya positif.

d. Semakin dalam kedalaman muka air tanah, besarnya excess pore pressure semakin menurun bahkan nilainya negatif.

\section{UCAPAN TERIMA KASIH}

Penulis mengucapkan terima kasih kepada:

1. Direktorat Riset dan Pengabdian Masyarakat, Direktorat Jenderal Penguatan Riset dan Pengembangan, Kementerian Riset, Teknologi dan Pendidikan Tinggi Sesuai dengan Kontrak Penelitian Nomor: 033/KM/PNT/2018.

2. Balai Pelestarian Cagar Budaya D.I. Yogyakarta yang telah memberikan izin melakukan penelitian di Candi Prambanan (Surat No.: 605/ E.18/PF/2018).

\section{DAFTAR PUSTAKA}

[1] Wahyudi, H.D., 2014, Kajian Stabilitas Fondasi Candi Prambanan Terhadap Beban Gempa Dengan Simulasi Numeris, Tesis S2 Geoteknik UGM, Yogyakarta, Indonesia.

[2] Tim Penyusunan Detail Engineering Design (DED), 2012, Kegiatan Studi Teknis Pelestarian Candi Siwa, Kompleks Candi Prambanan, BPCB Yogyakarta.
[3] Mithchell, J.K dan Soga, K., 2005, Fundamentals of Soil Behavior, John Wiley \& Sons, Inc., New Jersey.

[4] Venkatramaiah,C., 2006, Geotechnical Engineering, New Age International (P) Ltd, New Delhi.

[5] Verruijt, A., 2006, Soil Mechanics, Delft University of Technology, Dutch.

[6] Elnashai, A.S., Kim, S.J., Yun, G.J. dan Sidarta, D., 2006, The Yogyakarta Earthquake of May 27, 2006; MAE Center Report.

[7] Sengara, I.W., 2008, Seismic Hazard and Microzonation for A District in Banda Aceh City Post 2004 Great Sumatra Earthquake, diunduh tanggal 8 Desember 2010.

[8] Kusumawardhani, R., Lashari, Nugroho, U., Tri Cahyo, H., Analisis Tekanan Air Pori Clean Sand Menggunakan Metode Cyclic Shear-Strain Controlled. Jurnal Teknik Sipil \& Perencanaan. Nomor 1. Volume 17 - Januari 2015, hal: 63-72.

[9] Pusat Gempa Regional VII, Stasiun Geofisika Kelas I Yogyakarta, Badan Meterologi Klimatologi dan Geofisika, Stasiun Geofisika Yogyakarta.

[10] http://earthquake.usgs.gov/earthqu akes/search/ diakses 24 Juni 2018

[11] Suryolelono, K.B., 2007, Candi Prambanan Pasca Gempa Bumi, Forum Teknik Sipil No. XVII/3September 2007, http://puslit2.petra.ac.id/ejournal/i ndex.php/cef/article/download/17 363/17307, diunduh tanggal 10 Agustus 2018.

[12] Haryono, T., Supangat, S.S., Pramastuti, H. dan Marah, R., 2004, Pelapukan Batu Candi Siwa Prambanan dan Upaya Penangannya, Balai Pelestarian 
Tri Wahyu Kuningsih dan Dwi Novi Wulandari, Pengaruh Muka Air...

Peninggalan Purbakala

Yogyakarta, Bogem Kalasan.

[13] Rahmi, 2011, Perilaku Regangan-

Siklus Pembebanan Tanah Pasir

Prambanan dengan Uji Triaksial

Siklis, Tesis S2 Geoteknik UGM,

Yogyakarta, Indonesia

\section{Lampiran}

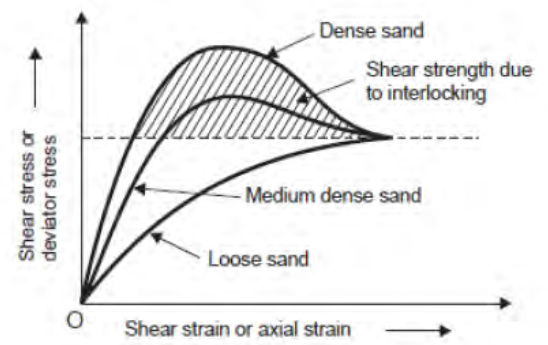

(a)
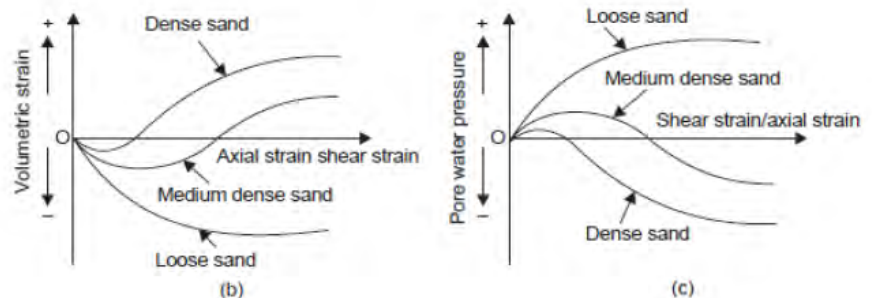

(c)

Gambar 1. Karakteristik tegangan-regangan pada pasir [4].

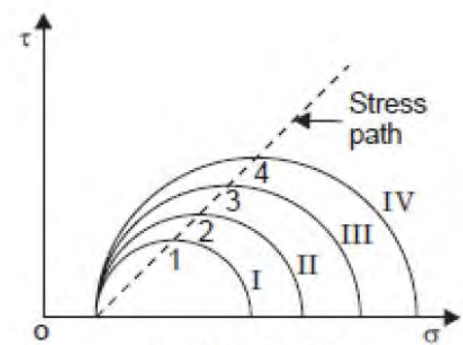

(a) Mohr's circles

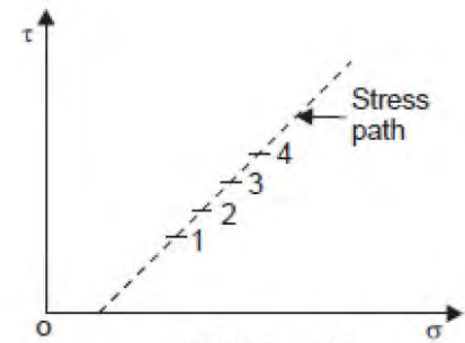

(b) Stress path

Gambar 2. Stress path untuk kasus $\sigma 1$ meningkat dan $\sigma 3$ konstan [4]. 


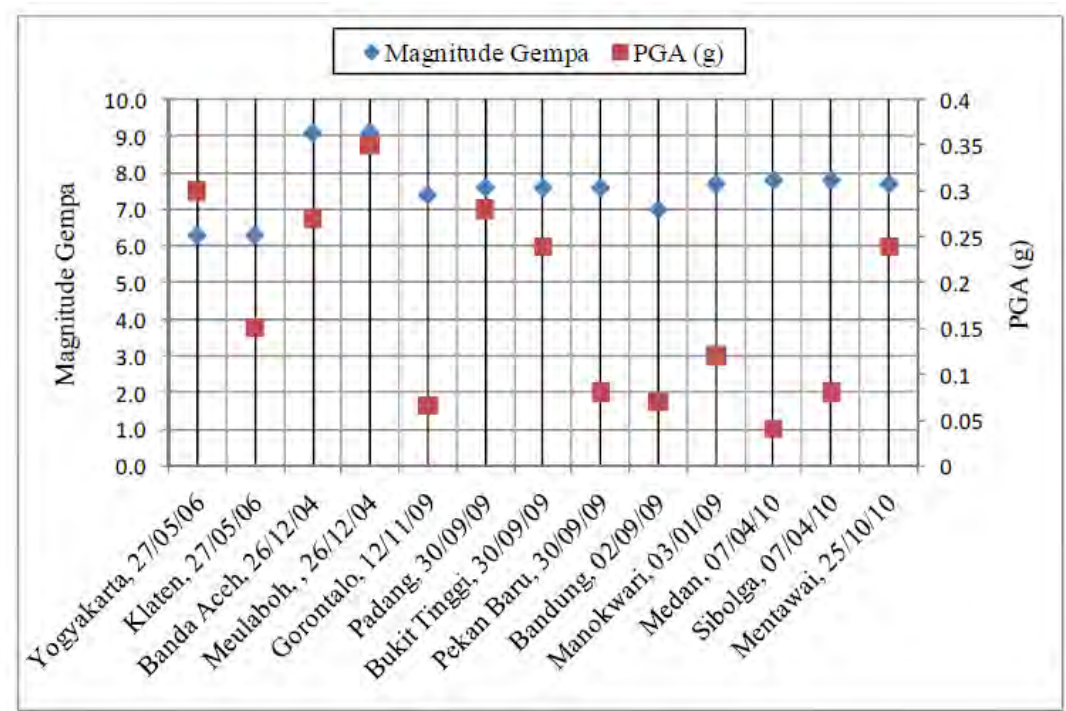

Gambar 3. Perbandingan PGA gempa-gempa Indonesia [6], [7]

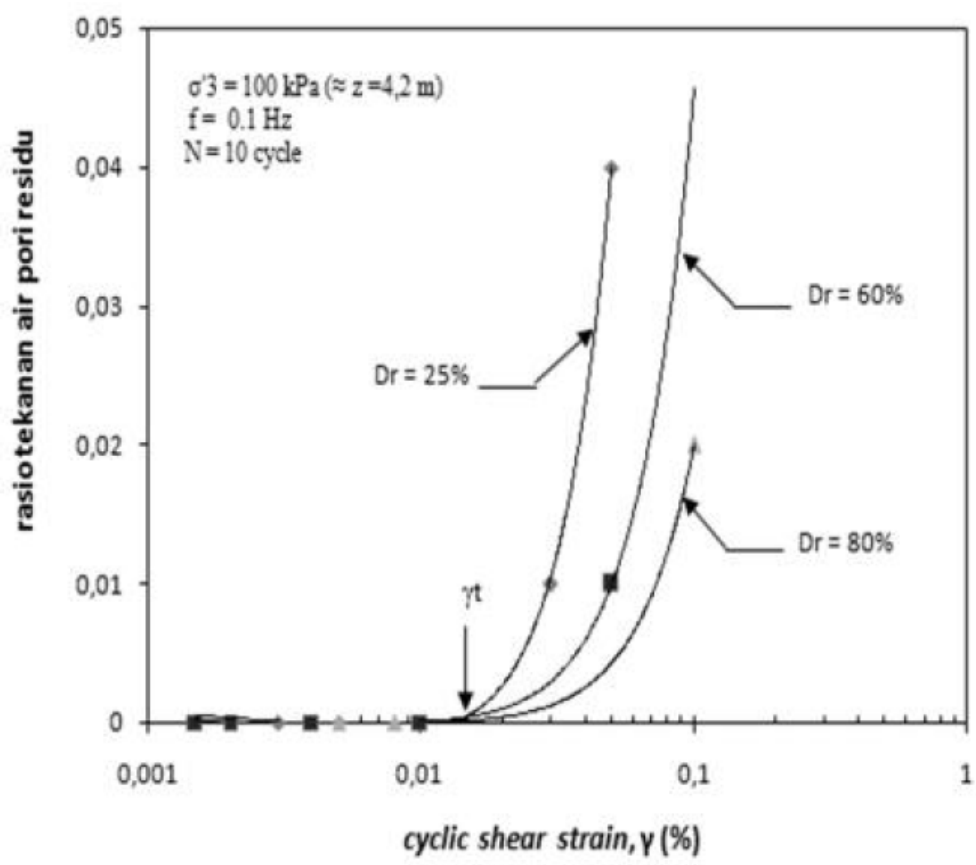

Gambar 4. Kenaikan tekanan air pori setelah $\mathrm{N}=10$ siklus untuk clean sand dengan variasi kepadatan relatif (Dr) dengan kondisi batas $\sigma^{\prime} 3$ sebesar $100 \mathrm{kPa}$ dan (f) $=0,1 \mathrm{~Hz}$ [8] 
Tri Wahyu Kuningsih dan Dwi Novi Wulandari, Pengaruh Muka Air...

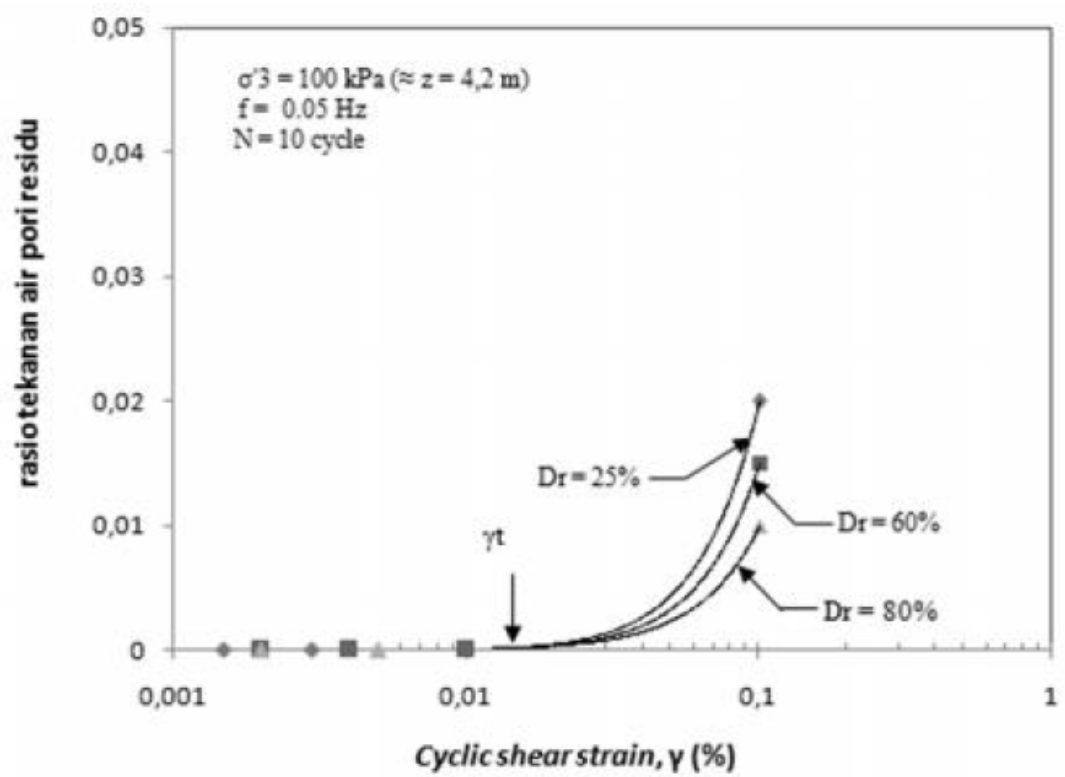

Gambar 5. Kenaikan tekanan air pori setelah $\mathrm{N}=10$ siklus untuk clean sand dengan variasi kepadatan relatif (Dr) dengan kondisi batas $\sigma^{\prime} 3$ sebesar $100 \mathrm{kPa}$ dan (f) $=0,05 \mathrm{~Hz}$ [8]
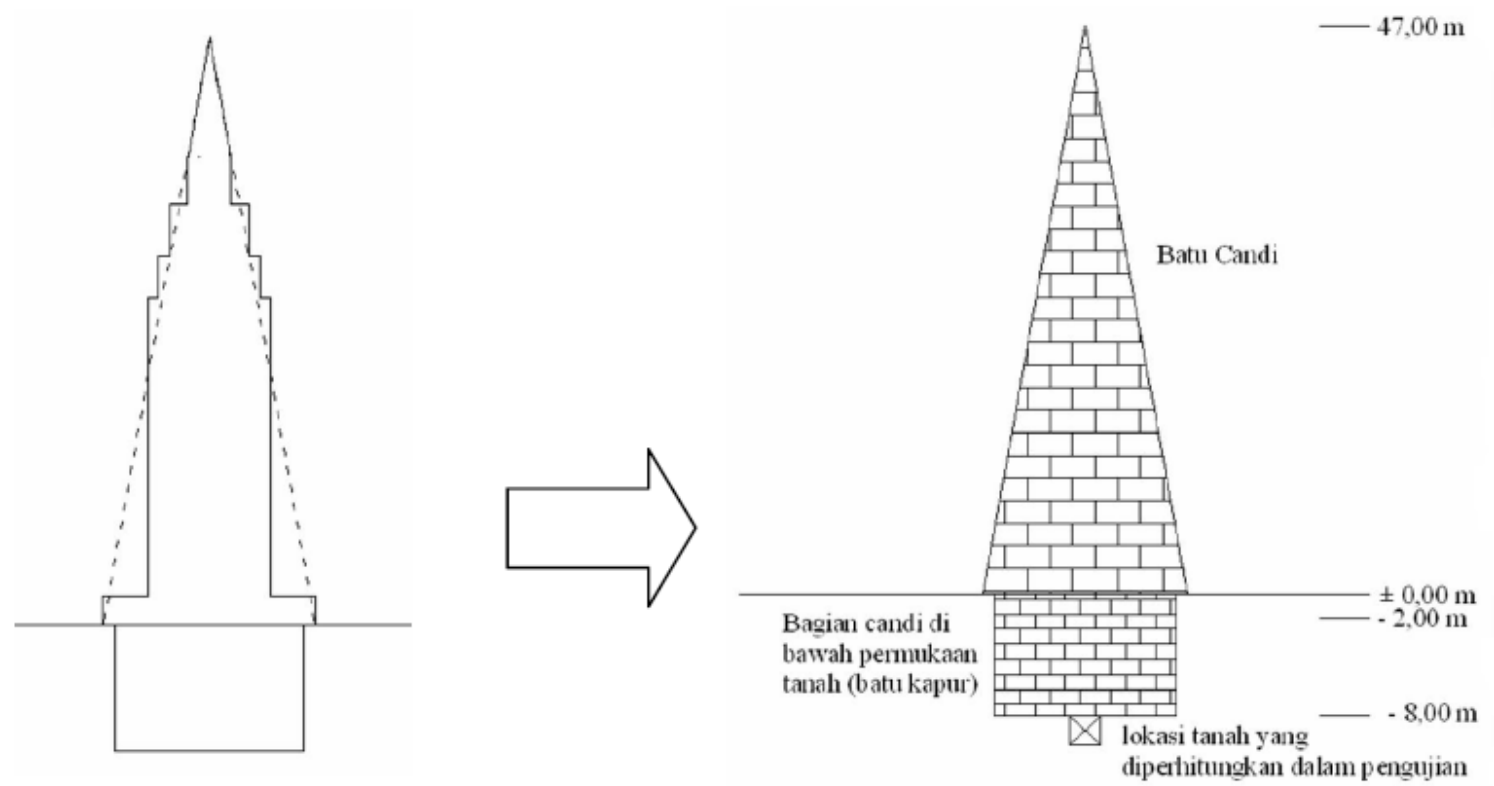

Gambar 6. Pemodelan tanah dasar Candi Siwa Prambanan [13] 


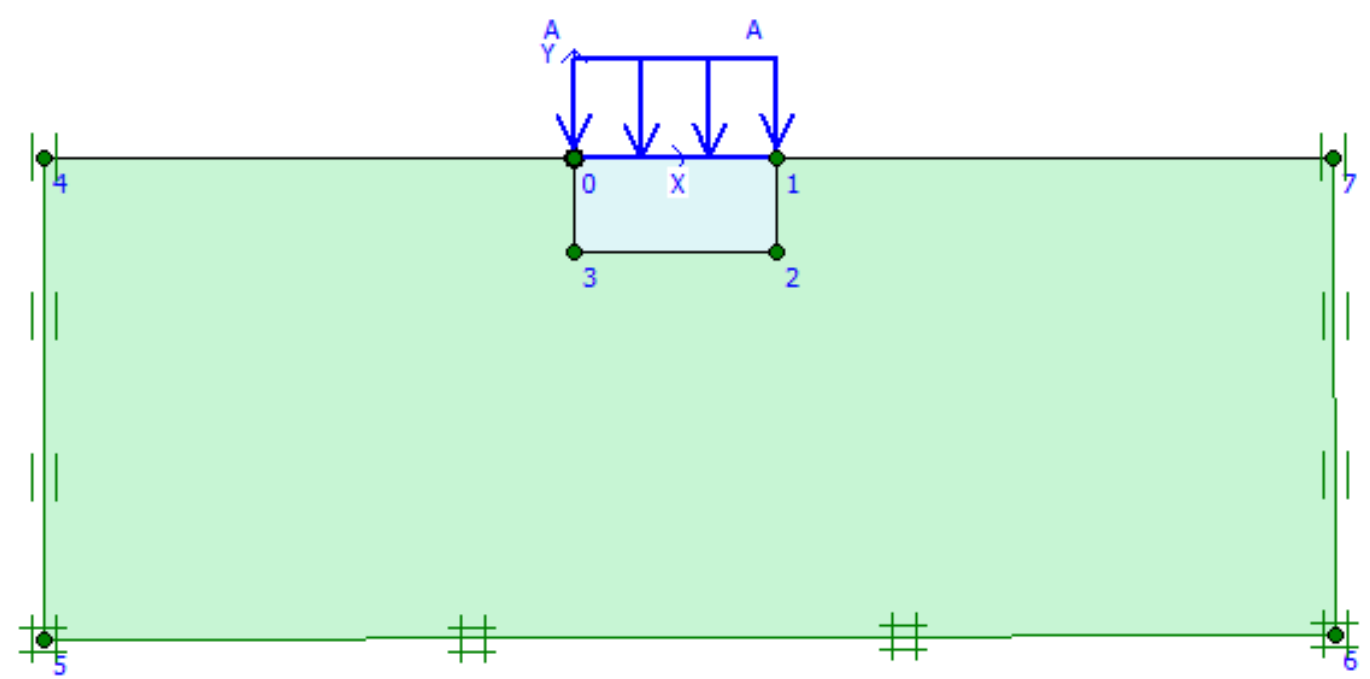

Gambar 7. Pemodelan tanah dasar Candi Siwa.

Pengaruh Kedalaman M.A.T. Terhadap Tegangan Efektif

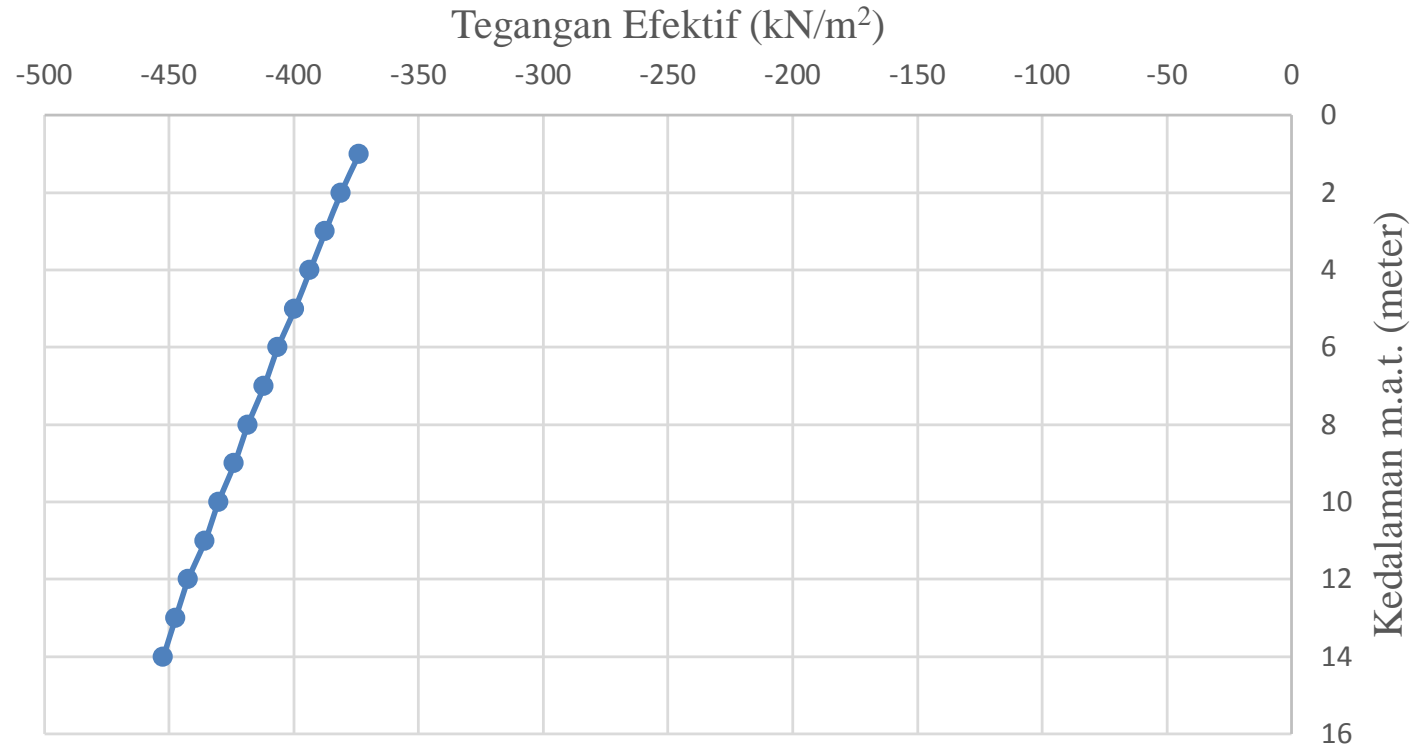

Gambar 8. Grafik pengaruh muka air tanah terhadap nilai tegangan efektif tanah 
Tri Wahyu Kuningsih dan Dwi Novi Wulandari, Pengaruh Muka Air...

Pengaruh Kedalaman M.A.T. Terhadap Excess Pore Pressure

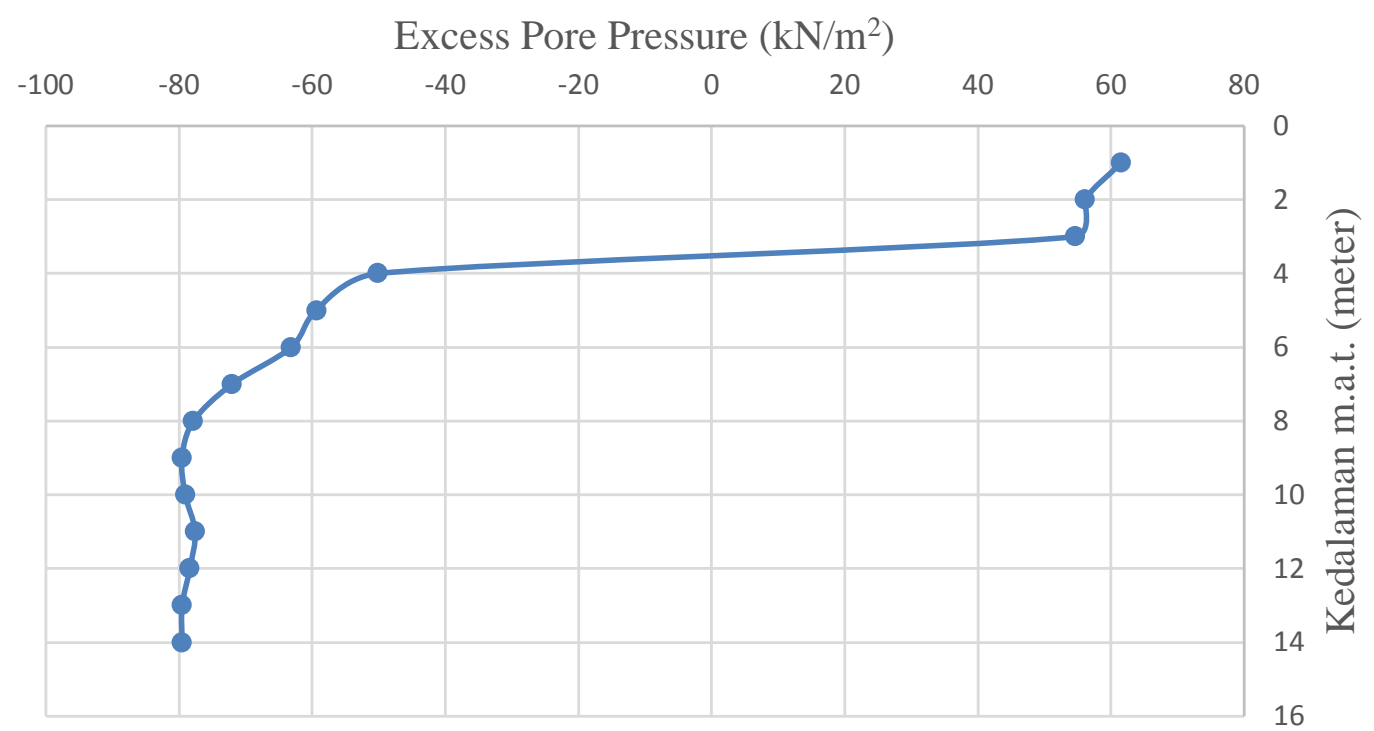

Gambar 9. Grafik Pengaruh Kedalaman Muka Air Tanah Terhadap Excesses Pore Pressure 